PF 2019 (LXXIII): 135-152

JOANNA KOWALCZYK

Instytut Filologii Polskiej

Uniwersytet Jana Kochanowskiego w Kielcach

ul. Żeromskiego 5, 25-369 Kielce

tel. (+48) 413497120

e-mail: jkowalczyk@ujk.edu.pl

\title{
UŻYTECZNOŚĆ I RELEWANCJA SEMANTYCZNA TERMINÓW PRAWNYCH DEFINIOWANYCH W SŁOWNIKACH OGÓLNEJ POLSZCZYZNY
}

SŁOWA KLUCZOWE: nomenklatura prawna, definicja, semantyka, leksykografia, słownik

KEYWORDS: legal nomenclature, definition, semantics, lexicography, dictionary

\section{UTILITY AND SEMANTIC RELEVANCE OF LEGAL TERMS DEFINED IN UNIVERSAL POLISH DICTIONARIES}

\begin{abstract}
The article analyzes correlations between the common and specialized variants of the Polish language. Diversity in meaning was the basis for the analysis. The material basis included four general lexicographic sources: Wielki słownik poprawnej polszczyzny (WSPP), the web-based Słownik języka polskiego PWN (SJP PWN), the web-based Wielki słownik języka polskiego PAN (WSJP PAN), Inny słownik języka polskiego (ISJP). The purpose of the study was to identify levels of convergence and divergence of legal definitions incorporated into dictionaries, and to determine whether they could be considered as an affirmative source of legal knowledge (even at a basic level).
\end{abstract}

\section{Wstęp}

Funkcjonowanie w społeczeństwie opierającym się na uporządkowanych założeniach państwowych wymaga opracowywania i implementowania określonych ustrojowo zasad komunikowania się członków wspólnoty w interakcjach 
oficjalnych. Ujednolicanie procedur rządzących sferą publiczną implikuje systematyzację terminologiczną i semantyczną kodu językowego. Między innymi $\mathrm{z}$ tego powodu

językoznawcy normatywiści stają przed trudnym zadaniem. Trzeba bowiem równocześnie inwentaryzować, opisywać i analizować bardzo liczne nowe zjawiska i procesy językowe oraz dokonywać ich wartościowania i oceny, gdyż takie są oczekiwania społeczne (Markowski 2004-2005, s. 132-133).

Świadomość nieprzystawania pewnych znaczeń, budujących korpus dyskursów sformalizowanych, umożliwia skonfrontowanie kodu zwyczajowego z kodem wykreowanym (Kowalczyk 2017, s. 128-134). W niniejszym opracowaniu uwaga została poświęcona podobieństwom i różnicom między kodem ogólnym a specjalistycznym (o charakterze prawnym). Przedmiotem oglądu uczyniono odpowiedniość bądź nieodpowiedniość semantyczną terminów prawnych wyjaśnionych w słownikach polszczyzny ogólnej względem ich znaczenia legislacyjnego.

Celem artykułu jest wskazanie i opis zbieżności oraz rozbieżności definicji wyjaśniających terminy z zakresu ustawodawstwa, które zostały umieszczone w słownikach języka polskiego; ustalenie, w jakim stopniu terminy z nomenklatury prawnej są uwzględniane w słownikach ogólnej polszczyzny; ustalenie, czy słowniki uniwersalne mogą być źródłem wiedzy prawnej (chociażby w stopniu podstawowym).

Źródłami leksykograficznymi wykorzystanymi do przeprowadzonej analizy były: Wielki słownik poprawnej polszczyzny (WSPP), internetowy Słownik języka polskiego PWN (SJP PWN), internetowy Wielki słownik języka polskiego PAN (WSJP PAN), Inny słownik języka polskiego (ISJP).

Za metodologiczną podstawę podjętych analiz uznano kryterium pragmatyczno-semantyczne, tj. dokonywano oglądu przez pryzmat funkcji i znaczenia konkretnych jednostek językowych w określonych sferach komunikacyjnych. Taka perspektywa umożliwiła porównanie treści definicji słownikowych z ich faktycznym znaczeniem prawnym. Jeżeli leksem miał charakter wieloznaczny, to dalszej analizie poddawano jedynie te definicje, które wchodziły w obszar pojęcia specjalistycznego. Kryterium określenia zbieżności i dywergencji w tym wymiarze obejmowało adekwatność merytoryczną i zakresową poszczególnych konceptów.

\section{Termin prawny jako sposób konceptualizowania rzeczywistości powszechnej}

Termin prawny jako narzędzie kreujące rzeczywistość pozajęzykową (formalną, bo przypisuje statusy osobom i rzeczom; faktyczną, bo powoduje realne konsekwencje) odnosi się do odbiorcy abstrakcyjnego i potencjalnego. 
W tym wymiarze założenia ustawodawcze rozszerzają zasięg aktów normatywnych na wszystkich obecnych i przyszłych adresatów norm prawnych. Fundament pragmatyczny opiera się na publicznej komunikacji powszechnej, w której nadawca oddziałuje na zbiorowego odbiorcę, przybierając postać hipostazowanego organu kolegialnego (np. sejmu, senatu, zgromadzenia narodowego) lub podmiotu instytucji (np. prezydenta). Z kolei treść komunikatów w takiej relacji ma charakter aktu symbolicznego, wykorzystywanego i wielokrotnie odtwarzanego w niezmienionej formie (McQuail 2007, s. 72).

W akcie takiej semiozy terminy prawne wymagają zachowania szczególnej staranności w odtwarzaniu ich istoty funkcjonalnej. Adekwatny opis stanowi więc podstawę właściwego wprowadzania terminu prawnego do publicznego, powszechnego obiegu i utrwalania jego znaczenia w świadomości odbiorców. Szczególnie w odniesieniu do jednostek pochodzących z nomenklatury specjalistycznej relewancja semantyczna staje się czynnikiem determinującym poznawczą wartość słowników ogólnych i konstytuuje ich status jako wszechstronnego źródła wiedzy. Nadanie znakom językowym przymiotu kreowania i modyfikowania rzeczywistości (taki atrybut posiadają terminy prawne) afirmuje podtrzymywanie ich wartości pragmatycznej poprzez formułowanie definicji odpowiadających faktycznej treści pojęcia specjalistycznego, chociażby w wymiarze uogólniającym.

\section{Terminy prawne w słownikach ogólnej polszczyzny}

Zbiory leksykograficzne o profilu ogólnym jako opracowania normatywne stanowią źródło wiedzy powszechnej. Włączenie hasła do zasobu słownika wiąże się więc z koniecznością opatrzenia go poprawnym wyjaśnieniem (m.in. słowniki o charakterze encyklopedycznym) oraz wskazaniami ortograficznymi i gramatycznymi (m.in. słowniki ortograficzne i ortoepiczne). Szczególne trudności eksplikacyjne mogą pojawić się w obrębie haseł specjalistycznych (prawnych, prawniczych), ponieważ

objaśnienie formułowane przez leksykografa dotyczy tego, jakie znaczenie przybiorą realizacje objaśnionego leksemu w nieskończonym zbiorze potencjalnych wypowiedzi, podczas gdy objaśnienia formułowane w procesie interpretacji prawa dotyczą realizacji leksemu w skończonej i z reguły niewielkiej liczbie wypowiedzi (Gizbert-Studnicki 1978, s. 38).

Mając świadomość rangi korpusów leksykograficznych oraz pragmatycznej istoty przepisów prawnych, podjęłam próbę odpowiedzi na pytanie, czy definicje terminów specjalistycznych zaczerpnięte z wybranych słowników języka polskiego mogą być dla użytkowników języka źródłem wiedzy specjalistycznej, chociażby w wymiarze uogólnionym. Do badania wykorzystano 300 losowo wybranych 
terminów prawnych. W analizowanych słownikach polszczyzny ogólnej odnaleziono 111 haseł. W wyniku oglądu opierającego się na kryterium relewancji semantycznej definicji słownikowych względem rzeczywistej pragmatyki konceptu wyodrębniono cztery główne aspekty pozwalające na rozpatrywanie relacji między językową normą ogólną a językową normą specjalistyczną:

1. Nietożsamość znaczenia jednostki leksykalnej funkcjonującej w normie ogólnej względem jej znaczenia w normie specjalistycznej.

2. Nieprecyzyjność definiowania terminów specjalistycznych w słownikach ogólnej polszczyzny.

3. Błędne definiowanie terminów specjalistycznych w słownikach ogólnej polszczyzny.

4. Zgodność definicji słownikowych z semantyką terminów specjalistycznych.

Pierwsza grupa obejmowała przykłady haseł, których znaczenie w normie specjalistycznej nie tworzyła relacji tożsamości lub bliskoznaczności z ich znaczeniem w polszczyźnie użytkowej lub/i potocznej. Do drugiej grupy włączono terminy prawne wyjaśnione lapidarnie lub parcjalnie. Do trzeciej klasy kwalifikowano inkorporowane do słowników terminy prawne zdefiniowane w sposób nieprawidłowy (niemający uzasadnienia $\mathrm{w}$ żadnym typie ich potencjalnego zastosowania - użytkowym, potocznym, specjalistycznym itd.). Ostatnia kategoria zgromadziła hasła właściwie wytłumaczone i mogące stanowić podstawę budowania wiedzy o dyskursie prawnym.

\section{Nietożsamość znaczenia terminu w normie specjalistycznej względem normy ogólnej}

Rozpoczynając rozpatrywanie kwestii semantycznej adekwatności definicji słownikowych w odniesieniu do znaczeń ustawodawczych, należy podkreślić, że ogólna odmiana polszczyzny co do zasady pełni funkcję narzędzia komunikacji powszedniej i nie wymaga włączania do swojego zasobu neosemantyzmów specjalistycznych, zwłaszcza jeżeli mają charakter wąskich znaczeniowo terminów. Wąski i wyspecjalizowany zakres niektórych pojęć z dziedziny prawodawstwa samoistnie wyklucza ich uwzględnianie w słownikach o profilu ogólnym. Warto zaznaczyć, że terminy prawne niemające przymiotu niekwestionowanych idei ustrojowych (takich, których znaczenie jest niezmienne) podlegają stałym modyfikacjom zakresowym (zmienia się ich zakres podmiotowy, przedmiotowy, jakościowy i ilościowy), np. zmienia się wysokość poszczególnych typów podatków, wymiar odpowiedzialności itd. Znaczenie takich haseł w słownikach ogólnej polszczyzny należałoby systematycznie aktualizować ze względu na możliwość częstych zmian w ich definiowaniu lub/i interpretowaniu prawnym. 
W konsekwencji użytkownik mógłby zostać wprowadzony w błąd co do znaczenia terminu względem obecnie obowiązujących ustaw.

Przykładami par konceptów funkcjonujących jako zestawienie jednostki pospolitej oraz terminu prawnego są m.in.: budowla vs. budowla, posiadać vs. posiadać.

W internetowym Słowniku języka polskiego PWN hasło budowla zostało wyjaśnione następująco:

- budowla «to, co zostało wybudowane» (SJP PWN).

Z kolei ISJP podaje, że:

- budowla «to obiekt, który wybudowano, trwale połączony z ziemią, np. budynek mieszkalny, stadion, most, zapora wodna» (ISJP).

Funkcjonalnie zbieżną definicję zawiera WSJP PAN, por.:

- budowla «wybudowany gdzieś obiekt połączony z gruntem w sposób trwały» (WSJP PAN).

Dostępne we wskazanych słownikach definicje potocznego pojęcia (ze względu na relację polisemiczności) mogą w niewielkim stopniu przybliżać ogólną właściwość budowli jako terminu prawnego. W zestawieniu $\mathrm{z}$ wyspecyfikowanym znaczeniem, jaki zyskała budowla w nomenklaturze specjalistycznej, koncept potoczny ma charakter uogólnionej klasy szerokiego zasięgu, obejmującej każdy wybudowany obiekt (zazwyczaj dużych rozmiarów). Natomiast z perspektywy prawnej budowla posiada własności dystynktywne, jednoznacznie wyróżniające ją spośród innych obiektów budowlanych, którymi są budynek i obiekt małej architektury, por.:

- Ilekroć w ustawie jest mowa o: (... 3) budowli - należy przez to rozumieć każdy obiekt budowlany niebędący budynkiem lub obiektem małej architektury (...) (art. 3 pkt $3 \mathrm{~PB}$ ).

Apofatyczność legislacyjnej definicji budowli (niebędący budynkiem lub obiektem małej architektury) wymagała precyzyjnego wskazania, czym są pozostałe dwa obiekty budowlane. Na podstawie przepisów ustawy Prawo budowlane ustalono, że budynek to nieruchomość mieszkalna lub użytkowa, por.:

- (...) [budynek] (...) to taki obiekt budowlany, który jest trwale związany z gruntem, wydzielony z przestrzeni za pomocą przegród budowlanych oraz posiada fundamenty i dach (art. 3 pkt 2 PB).

Z kolei obiekty małej architektury to konstrukcje niewielkie, rekreacyjne, ozdobne lub służące do utrzymania porządku, por.:

- Ilekroć w ustawie jest mowa o: (... 4) obiekcie małej architektury - należy przez to rozumieć niewielkie obiekty, a w szczególności:

a) kultu religijnego, jak: kapliczki, krzyże przydrożne, figury, 
b) posągi, wodotryski i inne obiekty architektury ogrodowej,

c) użytkowe służące rekreacji codziennej i utrzymaniu porządku, jak: piaskownice, huśtawki, drabinki, śmietniki (art. 3 pkt $4 \mathrm{~PB}$ ).

Zatem w świetle prawa budowla to rodzaj artefaktu pełniącego zazwyczaj funkcje infrastrukturalne. Dodatkowo może być zespołem elementów uznanych za strukturę tworzącą całość (np. cmentarz). Wyraźnie wąski zakres terminu specjalistycznego budowla pragmatycznie uzasadnia niewłączanie tej odrębnej klasy semantycznej (jako drugiego znaczenia) do słowników ogólnej polszczyzny.

Analogiczną relację stworzyły jednostka pospolita posiadać z jednostką specjalistyczną posiadać. W słownikach ogólnych hasło to zostało zdefiniowane w następujący sposób:

- posiadać «mieć coś na własność, być właścicielem czegoś» (WSPP);

- posiadać «być właścicielem czegoś, zwykle mającego dużą wartość materialną» (SJP PWN);

- posiadać «Jeśli posiadamy coś, zwykle coś wartościowego, to jesteśmy właścicielami tego» (ISJP);

- posiadać «mieć na własność coś cennego lub ważnego» (WSJP PAN).

Wyjaśnienia słownikowe wskazują, że posiadać to 'mieć coś na własność. Posiadać i być właścicielem traktowane w ogólnej odmianie polszczyzny jako jednostki synonimiczne mają odmienne znaczenia w ramach dyskursu oficjalno-prawnego. Posiadanie rzeczy i bycie właścicielem rzeczy w tym wypadku zyskały status odrębnych kategorii prawnych, por.:

- Posiadaczem rzeczy jest zarówno ten, kto nią faktycznie włada jak właściciel (posiadacz samoistny), jak i ten, kto nią faktycznie włada jak użytkownik, zastawnik, najemca, dzierżawca lub mający inne prawo, z którym łączy się określone władztwo nad cudzą rzeczą (posiadacz zależny) (art. $336 \mathrm{KC)}$ ).

Omówione przykłady pokazują możliwe różnice znaczeń w leksyce ogólnej i specjalistycznej. Na gruncie przepisów ustawowych posiadanie wiąże się z władaniem cudzą rzeczą, a nie z prawem własności do tej rzeczy. W ramach komunikacji oficjalnej oba terminy zyskują dystynkcję treściową i opisują odrębne koncepty. Ich dywergencja funkcjonalna znajduje uzasadnienie tylko na gruncie dyskursu profesjolektalnego. Z tego powodu nie ma potrzeby uwzględniania prawnego znaczenia hasła posiadać w ogólnych źródłach leksykograficznych. 


\section{Nieprecyzyjność definiowania terminów prawnych w słownikach ogólnej polszczyzny}

Kolejna grupa haseł obejmowała jednostki niewystarczająco precyzyjnie wyjaśnione. W ramach tej klasy znajdowały się hasła, których proweniencja jednoznacznie wskazywała na ich kwalifikację specjalistyczną (jednostki językowe mające tylko znaczenie prawne), oraz hasła specjalistyczne upowszechnione społecznie, które przeszły do języka ogólnego, ale zachowały swoje znaczenie.

W omawianej grupie pojęcia przynależące do nomenklatury specjalistycznej zostały zdefiniowane w sposób fragmentaryczny lub lapidarny, mogący wprowadzać w błąd co do istoty opisywanego zjawiska. Przykładami haseł zdefiniowanych parcjalnie lub nieprecyzyjnie są hodowla i dowód tożsamości.

Ze źródeł leksykograficznych włączonych do analizy wyekscerpowano cztery definicje hasła hodowla, por.:

- hodowla «wytwarzanie nowych odmian roślin i nowych ras zwierząt» (WSPP);

- hodowla «hodowanie zwierząt lub uprawa roślin» (ISJP);

- hodowla «opieka nad organizmami wykorzystywanymi przez człowieka» (WSJP PAN);

- hodowla "planowana opieka nad wzrostem i rozwojem zwierząt i roślin» (SJP PWN).

Pierwsze wyjaśnienie pojęcia hodowla zostało ograniczone tylko do jednego aspektu - zmiany genotypu. Nieakceptowalność drugiej definicji wiąże się z błędem strukturalnym. Definicja ma charakter tautologiczny (hodowla to hodowanie). Wyjaśnienia idem per idem apriorycznie stanowią błąd logiczny skutkujący antagonizmem poznawczym z perspektywy użytkownika, otrzymującego informację $\mathrm{z}$ kwantyfikatorem faktycznym ignotum per ignotum. Wyjaśnienie trzecie przybrało postać lapidarnej, ogólnikowej i synkretycznej konstrukcji, niepozwalającej na wyodrębnienie hodowli spośród różnorodnych zjawisk botanicznych (np. hodowla roślin vs. uprawa roślin), zoologicznych (np. hodowla zwierząt $v s$. chów), społecznych (np. niewolnictwo). Dopiero ostatnie wyjaśnienie (SJP PWN) stworzyło podstawę zrozumienia, czym jest hodowla, chociaż nie odnotowało jej celowości, która jest podstawową różnicą między hodowla a chowem. Za planowany efekt końcowy hodowli uważa się bowiem produkt ożywiony (np. żywe zwierzę, kwiat doniczkowy itp.), natomiast celem chowu jest produkt nieożywiony (np. mięso, mleko, kwiaty cięte).

Należy zaznaczyć, że omawiany termin skutecznie funkcjonuje zarówno w nomenklaturze specjalistycznej, jak i w języku potocznym. W obu wypadkach istota hodowli wiąże się z rozmnażaniem zwierząt i roślin oraz działaniami zmierzającymi do zachowania pewnych gatunków. Znaczenie ogólne odpowiada więc 
znaczeniu prawnemu, a trzy pierwsze wyjaśnienia nie są zgodne ani z praktyką społeczną, ani z zasadami ustawowymi, por.:

- hodowla zwierząt - zespół zabiegów zmierzających do poprawienia założeń dziedzicznych (genotypu) zwierząt gospodarskich, w zakres których wchodzi ocena wartości użytkowej i hodowlanej zwierząt gospodarskich, selekcja i dobór osobników do kojarzenia prowadzony w warunkach prawidłowego chowu (art. 2 pkt 4 OHiRZG);

- hodowla roślin - oznacza działalność zmierzającą do wytworzenia i zachowania odmian (art. 2 ust. 1 pkt 5 OPOR).

Kolejnym przykładem nieprecyzyjnego zdefiniowania terminu z zakresu komunikacji prawnej jest hasło dowód tożsamości. W SJP PWN odnotowano następującą definicję:

- dowód tożsamości «każdy dokument stwierdzający tożsamość danej osoby, np. paszport, dowód osobisty, prawo jazdy» (SJP PWN).

Z kolei ISJP podaje, że

- dowód tożsamości «to dokument taki, jak paszport, dowód osobisty lub prawo jazdy, stwierdzający tożsamość jakiejś osoby» (ISJP).

Należy zaznaczyć, że według polskiego ustawodawstwa istnieją tylko dwa rodzaje dokumentu tożsamości: dowód osobisty oraz paszport, por.:

- Dowód osobisty jest dokumentem stwierdzającym tożsamość i obywatelstwo polskie osoby (...) (art. 4 ust. $1 \mathrm{UoDO}$ );

- Dokument paszportowy (...) poświadcza obywatelstwo polskie, a także tożsamość osoby (...) (art. 4 UoDP).

Prawo jazdy nie jest dowodem tożsamości, lecz dokumentem uwierzytelniającym uprawnienia. Podstawowa funkcja tego typu dokumentów wiąże się z potwierdzeniem określonego statusu (np. legitymacja studencka) lub pewnych umiejętności (np. prawo jazdy), por.:

- Dokumentem stwierdzającym posiadanie uprawnienia do kierowania (...) pojazdem silnikowym (...) jest:

1) wydane w kraju:

a) prawo jazdy (...) (art. 4 ust. 1 UoKP).

Z powodu swej niepełnej samodzielności część $\mathrm{z}$ nich zawiera adnotację: ważne $z$ dokumentem tożsamości. Przywołane definicje zyskałyby atrybut precyzyjności, gdyby nie zawierały nieadekwatnego przykładu, tj. prawa jazdy, które przynależy do klasy tzw. dokumentów ze zdjęciem, ale nie ma przymiotu dowodu tożsamości. 


\section{Błędne definiowanie terminów prawnych w słownikach ogólnej polszczyzny}

Obok exemplów niepełnych lub nieprecyzyjnych definicji odnotowano również wyjaśnienia błędne. Za szczególnie wyrazisty przykład nieodpowiedniości zaproponowanej w słowniku definicji względem wyjaśnianego konceptu można uznać hasło zdolność prawna. Warto zaznaczyć, że proweniencja i użytkowość tego terminu odnosi się wyłącznie do obszaru nomenklatury profesjonalnej. Zatem $z$ dolność prawna jako jednostka leksykalna posiada tylko jedno znaczenie - specjalistyczne. Próbę zdefiniowania zdolności prawnej odnotowano w SJP PWN, por.:

- zdolność prawna «zdolność nabywania praw cywilnych oraz zaciągania zobowiązań» (SJP PWN).

Podane w słowniku wyjaśnienie terminu zdolność prawna jest de facto definicją zdolności do czynności prawnych - odrębnej kategorii cywilnej. Należy wyjaśnić, że zgodnie z założeniami ustawodawczymi zdolność prawna to przymiot wszystkich ludzi (bez ograniczeń wiekowych, narodowych itd.), co potwierdza przepis wyekscerpowany w kodeksu cywilnego, por.:

- Każdy człowiek od chwili urodzenia ma zdolność prawną (art. $8 \$ 1 \mathrm{KC}$ ).

Zatem ontologia zdolności prawnej opiera się na potencjale każdego człowieka do bycia podmiotem prawa przez całe życie.

Z kolei zdolność do czynności prawnej to możliwość działania i nawiązywania stosunków cywilnoprawnych we własnym imieniu (np. możliwość zawierania umów), warunkowana osiągnięciem odpowiedniego wieku oraz własnościami psychofizycznymi, por.:

- Pełną zdolność do czynności prawnych nabywa się z chwilą uzyskania pełnoletności (art. $11 \mathrm{KC}$ );

- Nie mają zdolności do czynności prawnych osoby, które nie ukończyły lat trzynastu, oraz osoby ubezwłasnowolnione całkowicie (art. $12 \mathrm{KC)}$ );

- Czynność prawna dokonana przez osobę, która nie ma zdolności do czynności prawnych, jest nieważna (art. $14 \mathrm{KC}$ ).

Biorąc pod uwage przepisy prawa, między zdolnościa prawna a zdolnościa do czynności prawnych nie ma zbieżności ani treściowej, ani zakresowej. Kategorie te posiadają odrębną pragmatykę i odnoszą się do różnych zjawisk społeczno- prawnych. Odnotowana w SJP PWN pomyłka definicyjna ma zapewne podłoże paronimiczne. Dla osób nieposiadających kompetencji terminologicznej i merytorycznej z zakresu prawa podobieństwo brzmieniowe zdolności prawnej i zdolności do czynności prawnych mogło sugerować zbieżność semantyczną. 
Do wyjaśnień błędnych zaliczono także m.in. definicję terminu kasacja, którą rejestrują SJP PWN, WSPP oraz ISJP. W dwóch ostatnich jednostkę tę przyporządkowano do grupy haseł opatrzonych kwantyfikatorem: hasło prawniczel termin prawniczy, zatem zdefiniowanie pojęcia apriorycznie wymagało sprawdzalności względem języka prawnego. Dokonany ogląd pozwolił jednak ustalić, że żadna z definicji nie odpowiadała znaczeniu ustawodawczemu. Szczególnie wyraźną nieścisłością odznaczała się próba wyjaśnienia istoty kasacji podjęta w ISJP, por.:

- Kasacja wyroku to jego unieważnienie przez sąd (ISJP).

W tym wypadku ujawnił się podwójny błąd obejmujący z jednej strony niepoprawność formalno-gramatyczną, z drugiej - semantyczną. Kasacja w użyciu normatywnym nie tworzy kolokacji (kasacja wyroku), lecz w funkcji terminu poddaje się łączliwości przyimkowej, tj. kasacja od, np.: kasacja od wyroku, kasacja od orzeczenia. Zatem konstrukcja kasacja wyroku nie funkcjonuje jako legislacyjny frazem nominatywny. Stosując jednostkę kasacja wyroku, odniesiono pojęcie prawne do klasy pojęć potocznych. W ten sposób utożsamiono kasację $\mathrm{z}$ anulowaniem czegoś, co z kolei wywołało kolejny błąd - zdefiniowanie niewłaściwego konceptu, obejmującego użytkowe znaczenia wyrazów anulować, skasować, znieść, unieważnić itp. W takiej formie wskazane hasło nie stanowi terminu prawnego, a jego definicja nie ma charakteru specjalistycznej wiedzy.

Kasację jako jednostkę syntetyczną odnotowano w WSPP oraz w SJP PWN, por::

- kasacja «odwołanie od orzeczenia sądu niższej instancji skierowane do sądu wyższej instancji» (SJP PWN);

- kasacja «odwołanie się od wyroku sądu niższej instancji do sądu wyższej instancji» (WSPP).

Włączone do słowników wyjaśnienia pojęcia kasacja zostały jednak obarczone nieścisłością związaną z instancyjnością orzeczniczą oraz nieścisłością merytoryczną dotyczącą ontologii pojęcia. Po pierwsze, kasacja sensu stricto nie jest formą odwołania od wyroku. Po drugie, nie zalicza się do działania w ramach instancyjności procesowej. W polskim systemie prawnym postępowania sądowe są dwuinstancyjne, a kasacja to procedura pozainstancyjna, która może zostać wszczęta po wydaniu orzeczenia przez sąd drugiej (tj. ostatniej) instancji. Kasacja nie posiada również atrybutu odwołania od orzeczenia sądu, lecz stanowi ostatnią możliwość uniknięcia wykonania prawomocnego wyroku. Sąd Najwyższy rozpatrujący kasację nie odnosi się bowiem do ustaleń i rozstrzygnięć sądów wydających wyroki, ale kontroluje zachowanie odpowiednich procedur podczas prowadzenia sprawy, por.: 
- Kasacja może być wniesiona tylko z powodu uchybień wymienionych w art. 439 [m.in. jeżeli w wydaniu orzeczenia brała udział osoba nieuprawniona lub niezdolna do orzekania bądź podlegająca wyłączeniu; sąd był nienależycie obsadzony lub którykolwiek z jego członków nie był obecny na całej rozprawie; sąd powszechny orzekł w sprawie należącej do sądu szczególnego albo sąd szczególny orzekł w sprawie należącej do właściwości sądu powszechnego (art. $439 \mathrm{KPK}$ )] lub innego rażącego naruszenia prawa, jeśli mogło ono mieć istotny wpływ na treść orzeczenia (art. $523 \S 1 \mathrm{KPK}$ ).

Kolejna fundamentalna różnica dotyczy tego, że odwołanie można składać od orzeczeń nieprawomocnych. Kasacja to szczególna kategoria prawna i dotyczy wyłącznie orzeczeń prawomocnych, por.:

- Od prawomocnego wyroku sądu odwoławczego kończącego postępowanie oraz od prawomocnego postanowienia sądu odwoławczego o umorzeniu postępowania (...) może być wniesiona kasacja (art. 519 KPK).

W żadnej z wyekscerpowanych definicji nie zostało również zaznaczone, że kasacja należy do nadzwyczajnych środków zaskarżenia i przysługuje stronom (podmiotom postępowania) wyłącznie w sprawach karnych. Zrównanie kasacji z kolejnym etapem sporu sądowego w drugiej instancji nie naświetla dystynkcji pragmatycznej konceptu i nie pozwala na uchwycenie ontologicznych oraz prakseologicznych atrybutów tego środka zaskarżenia.

\section{Zgodność definicji słownikowych z semantyką terminów prawnych}

Ostatnią grupę haseł prawnych odnotowanych w analizowanych słownikach polszczyzny ogólnej tworzyły terminy, których definicje leksykograficzne odpowiadały ich rzeczywistej treści w sensie prawnym. W tej kategorii znajdowały się hasła wyjaśnione w taki w sposób, że z punktu widzenia ustawodawstwa mogły zostać uznane za adekwatną interpretację przepisu. Przykładami definicji oddających ogólną pragmatykę konkretnych pojęć, funkcjonujących w komunikacji o charakterze oficjalnym, były m.in. wyjaśnienia jednostek: pełnoletni oraz zbrodnia. Wyjaśnienia tych terminów charakteryzowały się relewancją semantyczną względem szczególnej i wyspecyfikowanej pragmatyki dyskursu prawnego.

Jednostka pełnoletni została zarejestrowana w SJP PWN, WSPP oraz w ISJP, jednakże WSPP nie podaje wyjaśnienia pojęcia, dlatego dalszemu oglądowi zostały poddane hasła wyekscerpowane z SJP PWN i ISJP, por.:

- pełnoletni «mający wiek, w którym nabywa się pełnię praw obywatelskich oraz ponosi odpowiedzialność za swoje czyny» (SJP PWN); 
- pełnoletni «Ktoś, kto jest pełnoletni, osiągnął wiek, w którym nabywa się prawa obywatelskie i ponosi odpowiedzialność prawną. W wielu krajach ludzie stają się pełnoletni, gdy kończą 18 lat» (ISJP).

Istotny walor obu definicji dotyczy zachowania niejednorodności konceptu petnoletni na gruncie komunikacji oficjalnej. W dyskursie prawnym pełnoletność nie ogranicza się bowiem do faktu ukończenia osiemnastu lat. Kodeks cywilny obejmuje dwie kategorie osób pełnoletnich, por.:

- Pełnoletnim jest, kto ukończył lat osiemnaście (art. $10 \$ 1 \mathrm{KC}$ );

- Przez zawarcie małżeństwa małoletni uzyskuje pełnoletność (art. $10 \$ 2 \mathrm{KC}$ ).

Pełnoletność w pierwszym znaczeniu obejmuje wszystkie osoby co najmniej osiemnastoletnie, niezależnie od płci. Druga kategoria dotyczy wyłącznie kobiet, które ukończyły szesnaście lat i którym sąd zezwolił na zawarcie związku małżeńskiego, por.:

- Nie może zawrzeć małżeństwa osoba niemająca ukończonych lat osiemnastu. Jednakże z ważnych powodów sąd opiekuńczy może zezwolić na zawarcie małżeństwa kobiecie, która ukończyła lat szesnaście (...) (art. $10 \$ 1 \mathrm{KRiO})$.

Zatem zgodnie z kodeksem cywilnym do kategorii osób pełnoletnich eksplicytnie zalicza się tych, którzy ukończyli osiemnaście lat (bez względu na płeć), oraz zamężne kobiety, które ukończyły lat szesnaście.

Z kolei kodeks karny określa implicytną klasę osób pełnoletnich. Zgodnie z założeniami ustawy kategoria ta obejmuje osoby mające co najmniej siedemnaście lat i z tego powodu mogące ponosić odpowiedzialność za swoje czyny, por.:

- Na zasadach określonych w tym kodeksie odpowiada ten, kto popełnia czyn zabroniony po ukończeniu 17 lat (art. $10 \$ 1 \mathrm{KK}$ ).

Z punktu widzenia adekwatności prawotwórczej definicje słownikowe oddają w sposób uogólniony, ale precyzyjny podstawowe znaczenie konceptu pełnoletni, a tym samym konceptu pokrewnego, tj. pełnoletność.

Drugi przykład: zbrodnia, również został zdefiniowany zgodnie z jego znaczeniem prawnym. Hasło zbrodnia odnotowano we wszystkich analizowanych źródłach leksykograficznych, tj. w SJP PWN, WSPP, WSJP PAN ${ }^{1}$ oraz ISJP. Odpowiedniość treści definicji względem rzeczywistości prawnej zachowały wyjaśnienia SJP PWN, WSPP, ISJP, por.:

- zbrodnia «ciężkie przestępstwo» (SJP PWN);

1 Definicja pojęcia zbrodnia zawarta w WSJP PAN nie została włączona do analizy, ponieważ odnosiła koncept wyłącznie do działań przeciwko człowiekowi, co ograniczyło zakres zbrodni jako kategorii prawnej. Zgodnie z kodeksem karnym zbrodnia może również dotyczyć m.in. przestępstw przeciwko mieniu i przeciwko dobrom szczególnie ważnym dla kultury (art. $125 \$ 2 \mathrm{KK}$ ). 
Użyteczność i relewancja semantyczna terminów prawnych definiowanych w słownikach... 147

- zbrodnia «poważne przestępstwo» (WSPP);

- zbrodnia «Zbrodnia to ciężkie przestępstwo, np. morderstwo lub umyślne okaleczenie kogoś» (ISJP).

Zgodnie z art. 7 kodeksu karnego zbrodnia jest jednym z dwóch rodzajów przestępstw, drugim jest występek, ale zbrodnia to przestępstwo ciężkie i popełniane zawsze umyślnie, por.:

- Przestępstwo jest zbrodnią albo występkiem (art. $7 \$ 1 \mathrm{KK}$ );

- Zbrodnię można popełnić tylko umyślnie; występek można popełnić także nieumyślnie (...) (art. $8 \mathrm{KK})$.

Odnosząc przywołane definicje słownikowe do założeń ustawowych, wyjaśnienia leksykograficzne należy uznać za oddające istotę pojęcia zbrodnia.

\section{Słownik polszczyzny ogólnej z perspektywy edukacji prawnej}

Interpretacja dokonanych ustaleń faktycznych opierała się przede wszystkim na kryterium jakościowym, na którego podstawie możliwa stała się ocena użyteczności słowników ogólnych w kontekście wiedzy specjalistycznej. Ze względu na charakter artykułu miernik ilościowy przybrał postać wstępnego i wtórnego elementu opisu, a badanie dotyczyło przede wszystkim kwestii jakościowych. $\mathrm{Na}$ trzysta losowo wybranych terminów prawnych w słownikach poddanych oglądowi (WSPP, SJP PWN, WSJP PAN, ISJP) odnaleziono sto jedenaście haseł, co stanowiło 37\% zestawu. Słowniki ogólnej polszczyzny włączały do swoich zasobów przede wszystkim hasła spopularyzowane na gruncie komunikacji powszechnej (np. mandat, podatek, przestępstwo itp.). Przyczyny ograniczeń ilościowych wiązały się także ze strukturą jednostek specjalistycznych, które charakteryzuje postać analityczna (dowód osobisty, dowód tożsamości, odpowiedzialność karna, postępowanie odwoławcze itp.). Z kolei dostępność haseł w poszczególnych słownikach różniła się ze względu na odmienne determinanty doboru: czynnik tematyczny (słowniki poprawnościowe), czynnik arbitralności (słowniki uniwersalne), czynnik ilościowy (słowniki internetowe i elektroniczne vs. słowniki drukowane). Z powodu rozbieżności ilościowych nie dokonano komparatywnego studium statystycznego, ponieważ nie mogłoby stanowić podstawy uzyskania reprezentatywnych wyników.

Właściwy etap badania miał charakter analizy funkcjonalnej, tj. dotyczył oceny adekwatności treściowej wyekscerpowanych definicji terminów prawnych. Dokonując oglądu haseł słownikowych opisujących koncepty specjalistyczne, wykazano, że można je przyporządkować do czterech grup: nietożsamości znaczeniowej, nieprecyzyjności opisu, błędnego definiowania oraz adekwatności 
semantycznej. Już ze względu na pojawienie się pewnej liczby haseł, których wyjaśnienie pojęć miało charakter parcjalny bądź błędny, można przyjąć, że słowniki ogólnej polszczyzny w aktualnej postaci nie przedstawiają afirmowanego źródła wiedzy prawnej. W każdym słowniku odnotowano hasła, które należało przyporządkować do kategorii definicji błędnych lub nieprecyzyjnych. Warto zaznaczyć, że grupa obejmująca błędne wyjaśnienia znaczeń prawnych liczyła nie więcej niż kilka przykładów dla każdego słownika (WSJP PAN - dowód rzeczowy, młodociany, wykroczenie, zbrodnia; SJP PWN - intercyza, dowód rzeczowy, kasacja, młodociany, występek, zdolność prawna; WSPP - kasacja; ISPP - kasacja, młodociany). Ze względu na główny cel badania uwagę zwrócono przede wszystkim na przyjęte reguły i efekty opracowywania oraz definiowania haseł.

Dokonany ogląd pozwolił ustalić, że systemowe przyczyny nieadekwatności merytorycznej wiązały się z niedostateczną efektywnością procedur wykorzystywanych do budowania korpusu haseł prawnych. Oprócz uchybień wynikających ze złożoności materii opisu (np. zdolność prawna) szczególnie istotnym faktem, wpływającym na relewancję semantyczną, okazała się reprodukcja definicji, powielających błędne wyjaśnienia terminów. Niewystarczająca refleksja nad dostępnymi wyjaśnieniami skutkowała multiplikowaniem omówień niepoprawnych, por.:

- dowód rzeczowy «przedmiot mający znaczenie dla wykrycia lub potwierdzenia winy oskarżonego» (SJP PWN);

- dowód rzeczowy «przedmiot związany z popełnionym przestępstwem, świadczący o winie oskarżonego» (WSJP PAN).

Należy dodać, że funkcja dowodu rzeczowego opiera się na jego potencjale ustalenia okoliczności rozpatrywanej sprawy. Dowód rzeczowy może być podstawą uznania czyjejś winy bądź stwierdzenia jej braku (sprawy sądowe mogą zakończyć się zarówno wyrokiem skazującym, jak i uniewinniającym). Ponadto dowody rzeczowe nie występują jedynie w sprawach karnych (nie dotyczą tylko osób o statusie oskarżonych), ale także np. w postępowaniach o wykroczenia (por. art. $44 \$ 1 \mathrm{KPoW}$ ).

Drugim istotnym czynnikiem błędogennym stało się utrwalanie stereotypów potocznych, zakorzenionych społecznie w postaci spetryfikowanych ideologemów ludowych (utartych, często intuicyjnych, formuł), por.:

- intercyza «umowa przedmałżeńska ustalająca sprawy majątkowe przyszłych małżonków» (SJP PWN).

Zgodnie z założeniami ustawowymi (por. art. $47 \$ 1 \mathrm{KRiO}$ ), potwierdzonymi w literaturze przedmiotu, intercyza jest umową przedmałżeńską lub małżeńską, por.: 
małżonkowie mogą przez zawarcie majątkowej umowy małżeńskiej (tzw. intercyzy) ustanowić umowny ustrój majątkowy. Poprzez intercyzę małżonkowie mogą wspólność ustawową rozszerzyć, ograniczyć albo ustanowić rozdzielność majątkową. Umowny ustrój majątkowy małżonkowie mogą zawrzeć w trakcie trwania małżeństwa lub przed jego zawarciem (Boratyński 2009, s. 73).

Trzecim czynnikiem wprowadzającym nieścisłości semantyczne był determinant paronimiczno-polisemiczny. Konsekwencją zbieżności brzmieniowej połączonej z odmienną treścią potocznych i specjalistycznych jednostek językowych stały się błędy merytoryczne, por.:

- młodociany «Młodociany pracownik lub przestępca to pracownik lub przestępca niepełnoletni» (ISJP).

Utożsamienie zarówno młodocianego pracownika, jak i młodocianego sprawcy czynów niedozwolonych z osobą niepełnoletnią nie ma uzasadnienia prawnego. Według norm odnoszących się do kodeksu pracy młodociany to „osoba, która ukończyła 15 lat, a nie przekroczyła 18 lat” (art. $190 \$ 1 \mathrm{KP}$ ). Z kolei zgodnie z kodeksem karnym młodociany to pełnoletni „sprawca, który w chwili popełnienia czynu zabronionego nie ukończył 21 i w czasie orzekania w pierwszej instancji 24 lat" (art. $115 \$ 10 \mathrm{KK})$.

Przeprowadzona analiza, dotycząca semantycznej trafności haseł, wykazała niepełną wystarczalność ewaluacji procedur leksykograficznych. Ze względu na niepewność relewancji funkcjonalnej definicji słownikowych względem założeń ustawodawczych i rzeczywistości realnoprawnej rekomendacją merytoryczną pozostaje realizowanie projektów leksykograficznych, w których uczestniczą zespoły interdyscyplinarne opracowujące hasła specjalistyczne. W obecnym wymiarze użyteczności słowników ogólnych w kontekście wiedzy specjalistycznej należy usytuować na poziomie adekwatności relatywnej.

\section{Zakończenie}

Jak każde narzędzie, język powinien (...) być wykorzystywany w sposób przemyślany i skuteczny. Dlatego sposób formułowania myśli, dobór wyrazów i połączeń wyrazowych, wybór odpowiednich środków stylistycznych nie jest obojętny ani dla tego, kto mówi lub pisze, ani dla tego, kto słucha lub czyta (Markowski 1999, w: WSPP 2004, s. 11).

Słowniki o charakterze ogólnym jako źródła poprawności językowej oraz wiedzy praktycznej posiadają potencjał istotnego narzędzia samokształcenia przeznaczonego dla każdego użytkownika języka. Wskazania dotyczące kwestii formalnych (leksykalnych, gramatycznych, ortograficznych, fonetycznych) połączone z opisem treściowym haseł pozwalają na uzyskanie informacji normatywnej 
i semantycznej. Decyzja o włączeniu do słownika ogólnej polszczyzny jednostek o charakterze szczególnym powinna być zatem poprzedzona refleksją jego twórców na temat tego, że informacje w nim zawarte staną się przedmiotem użytkowania, nauczania i popularyzacji (por. Markowski 2006, s. 30). W tym wypadku słownik staje się zmaterializowaniem polityki językowej i działalności kulturalnojęzykowej leksykografów. Prakseologia kształtowania świadomości językowej użytkowników ma bowiem

charakter prewencyjny - polegający na upowszechnianiu wiedzy o języku i o jego kulturze, albo interwencyjny, którego zadaniem jest rozstrzyganie wątpliwości językowych. Często zresztą oba aspekty tej działalności w konkretnych działaniach występują wspólnie (Markowski 2006, s. 75).

Przyjmując tę perspektywę oglądu, językowa norma skodyfikowana opiera się na deskrypcji (opisie) i preskrypcji (zaleceniach). Z jednej strony opisuje, wyjaśnia, egzemplifikuje, z drugiej - prezentuje rekomendacje poprawnościowe. Adekwatność tych dwu komponentów, ze szczególnym uwzględnieniem relewancji semantycznej haseł specjalistycznych, daje możliwość właściwego kształtowania i rozbudowania siatki pojęciowej u odbiorcy, który czerpie wiedzę o świecie również ze źródeł leksykograficznych o profilu ogólnym. W odniesieniu do terminów funkcjonujących w obszarze dyskursów profesjolektalnych opracowania leksykograficzne mogą odgrywać szczególną rolę - upowszechniania nomenklatury specjalistycznej oraz kształtowania kompetencji językowych i komunikacyjnych (por.: Kowalczyk 2015; Zbróg 2016 i in.). Zapewnienie pełnej relewancji definicyjnej staje się $\mathrm{w}$ tej perspektywie warunkiem sine qua non zachowania poznawczej i edukacyjnej roli słownika, ponieważ „standard skodyfikowany bywa przywoływany jako swoisty wzorzec językowy” (Zgółka 2017, s. 72).

\section{Materiały źródłowe wraz z wykazem skrótów}

KC - Kodeks cywilny z dn. 23 kwietnia 1964 r., DzU 1964 nr 16 poz. 93;

KK - Kodeks karny z dn. 6 czerwca 1997 r., DzU 1997 nr 88 poz. 553;

KP - Kodeks pracy z dn. 26 czerwca 1974 r., DzU 1974 nr 24 poz. 141;

KPK - Kodeks postępowania karnego z dn. 6 czerwca 2997 r., DzU 1997 nr 89 poz. 555;

KPoW - Kodeks postępowania w sprawach o wykroczenia z dn. 26 sierpnia 2001 r., DzU 2001 nr 106 poz. 1148;

KRiO - Kodeks rodzinny i opiekuńczy z dn. 25 lutego 1964 r., DzU 1964 nr 9 poz. 59;

OHiRZG - Ustawa o organizacji hodowli i rozrodzie zwierząt gospodarskich z dn. $29 \mathrm{czerw}$ ca 2007 r., DzU 2007 nr 133 poz. 921; 
Użyteczność i relewancja semantyczna terminów prawnych definiowanych w słownikach... 151

OPOR - Ustawa o ochronie prawnej odmian roślin z dn. 26 czerwca 2003 r., DzU 2003 nr 137 poz. 1300 ;

PB - Ustawa prawo budowlane z dn. 7 lipca 1994 r., DzU 1994 nr 89 poz. 414;

SJP PWN - Słownik języka polskiego PWN, https://sjp.pwn.pl;

UoDO - Ustawa o dowodach osobistych z dn. 6 sierpnia 2010 r., DzU 2010 nr 167 poz. 1131;

UoDP - Ustawa o dokumentach paszportowych z dn. 13 lipca 2006 r., DzU 2006 nr 143 poz. 1027;

UoKP - Ustawa o kierujacych pojazdami z dn. 5 stycznia 2011 r., DzU 2011 nr 30 poz. 151;

WSJP PAN - Wielki słownik języka polskiego PAN, www.wsjp.pl;

ISJP - Inny słownik języka polskiego, red. M. Bańko, Warszawa 2000;

WSPP - Wielki słownik poprawnej polszczyzny, red. A. Markowski, Warszawa 2004.

\section{Bibliografia}

Austin, J.L. (1993). Mówienie i poznawanie. Warszawa: Wydawnictwo Naukowe PWN.

Boratyński, J. (2009). Ochrona fizyczna osób i mienia. Zagadnienia prawne. Warszawa: Wydawnictwa Szkolne i Pedagogiczne.

Kowalczyk, J. (2015). Brak kompetencji komunikacyjnych a zakłócenia w porozumiewaniu się, W: E. Męcina-Bednarek (red.), Optyka zagrożeń procesu porozumiewania się w życiu codziennym (29-41). Kielce: Oficyna Wydawnicza Staropolskiej Szkoły Wyższej.

Kowalczyk, J. (2017). Pragmatyka komunikacji urząd - obywatel. Kraków: Wydawnictwo Libron.

Gizbert-Studnicki, T. (1978). Wieloznaczność leksykalna w interpretacji prawniczej. Kraków: Wydawnictwo Uniwersytetu Jagiellońskiego.

Markowski, A. (2004-2005). Językoznawstwo normatywne dziś i jutro: zadania, szanse, zagrożenia, Postscriptum Polonistyczne, 2-1 (48-49), 126-139.

Markowski, A. (2006). Kultura języka polskiego. Teoria. Zagadnienia leksykalne. Warszawa: Wydawnictwo Naukowe PWN.

McQuail, D. (2007). Teoria komunikowania masowego. Warszawa: Wydawnictwo Naukowe PWN.

Zbróg, P. (2016). O potrzebie ustawicznego kształcenia kompetencji komunikacyjnych uczniów we współczesnej szkole. W: E. Męcina-Bednarek (red.), Komunikacja w przestrzeni edukacyjnej (103-114). Kielce: Oficyna Wydawnicza Staropolskiej Szkoły Wyższej.

Zgółka, T. (2017). Poprawność językowa w oczach retoryki. W: B. Sobczak (red.), Powinowactwa retoryki (69-81). Poznań: Wydawnictwo Naukowe Uniwersytetu Adama Mickiewicza w Poznaniu. 


\section{Streszczenie}

Artykuł porusza kwestie korelacji ogólnej i specjalistycznej odmiany polszczyzny. Odmienność w sposobach nadawania znaczeń stanowiła podstawę podjętych analiz. Bazę materiałową tworzyły cztery źródła leksykograficzne o profilu ogólnym: Wielki słownik poprawnej polszczyzny (WSPP), internetowy Słownik języka polskiego PWN (SJP PWN), internetowy Wielki słownik języka polskiego PAN (WSJP PAN), Inny słownik języka polskiego (ISJP). Przedmiotem oglądu uczyniono odpowiedniość semantyczną terminów prawnych wyjaśnionych w słownikach polszczyzny ogólnej względem ich znaczenia legislacyjnego. Celem badania było określenie poziomów zbieżności i dywergencji definicji prawnych inkorporowanych do słowników oraz ustalenie, czy mogą one zostać uznane za afirmowane źródło wiedzy prawnej (chociażby w stopniu podstawowym). 